\title{
Subkultura kulturních kreativců a alternativní životní styl v Pravém domácím časopisu \\ Marta Kolářová
}

DOI: 10.21104/CL.2019.1.05

The Cultural Creatives' Subculture and Alternative Lifestyle in the Magazine 'Pravý domácí časopis'

\begin{abstract}
The paper focuses on Czech alternative lifestyles and subcultures that cannot be defined by music and youth, hence using the concept of cultural creatives (Ray - Anderson 2000). This subculture has been formed by a convergence of social movements and countercultures since the 1960s. Based on a qualitative media analysis of Czech alternative lifestyle magazine (Pravý domácí časopis - Real Homemade Magazine) which represents and co-creates alternative lifestyles and values with focus on environmental, spiritual and women's issues, the author looks for linkages of specific lifestyles and practices. They are united by values and principles, such as: turn to nature, freedom and autonomy, and change of consciousness. Also, the issues of collective identity, community and neo-tribes, are addressed.
\end{abstract}

\section{Key words}

subculture, lifestyle, values, cultural creatives, sustainability, spirituality

\section{Acknowledgment}

Studie vznikla v rámci programu Strategie AV 21 „Globální konflikty a lokální souvislosti“ (č. 910018). Autorka děkuje za komentáře k článku Janě Stachové, Ondřeji Danielovi, Jiřímu Almerovi, Karlovi Šimovi, Zuzaně Joskové, Danielu Rathousovi a dvěma anonymním recenzentům.

\section{Contact}

PhDr. Marta Kolářová, PhD., Sociologický ústav AV ČR, v. v. i., Jilská 1, 11000 Praha 1, Czech Republic; e-mail: marta.kolarova@soc.cas.cz.

\section{Jak citovat / How to cite}

Kolářová, Marta. (2019). Subkultura kulturních kreativců a alternativní životní styl v Pravém domácím časopisu. Český lid 106, 85-105. doi:http:// dx.doi.org/10.21104/CL.2019.1.05 


\section{Úvod}

Výzkum subkultur se ve světě od 70. let a později také u nás orientoval převážně na hudební subkultury mládeže. V české i zahraniční literatuře najdeme detailní popisy a analýzu alternativních životních stylo̊, které se pojí s punkem, technem, hip hopem a dalšími hudebními uskupeními. V naší společnosti se ale objevují další alternativní životní styly, které se nedají vysvětlit jen vztahem $\mathrm{k}$ hudbě nebo mládeži. V tomto textu se chci zabývat jevy, které kolem sebe v čím dál větší míře pozoruji: pěstování si vlastní zeleniny bez chemie, stavění př́rodních domů, navštěvování kurzů osobního rozvoje či ženských kruhů, výroba domácí kosmetiky, nošení bosobot, nakupování bez odpadu, vyhledávání alternativního vzdělávání, domácí porody či domácí léčení prrírodními prostř̌edky. Zajímá mne, co mají tyto fenomény společného, co stojí v jejich pozadí a zda je možné pro ně v teoriích subkultur najít nějaké vhodné označení a teoretický koncept, který by je zarámoval.

Tato témata se již objevují v masmédiích a populární kultuře, je to např́klad hnutí zero waste (bez odpadu), které v Česku nalézá řadu příznivců, nebo udržitelná móda, jejíž protagonistka je označována novináŕi za módní revolucionářku. Stejně tak se v bulváru můžeme dočíst o kněžce bohyně prosazující domácí porody a pohanské rituály. V televizi běžíjiž několik let pořad Herbár zabývající se bylinami, zdravým vařením, tradicemi a regionálními potravinami. Reprezentace této tematiky v masmédiích představuje ale jen střípky celku, proto jsem se k poskládání detailnějš́ího obrazu alternativních životních stylů obrátila k jinému zdroji - alternativnímu médiu, který přistupuje k alternativním životním stylům komplexně a zdola a dává zaznít nejen expertům, ale především samotným aktérům této (sub)kultury. Vybrala jsem médium, které se orientuje na alternativní životní styl a představuje širokou škálu jeho jednotlivých aspektů v různých oblastech života (strava, bydlení, tvoření, zahradničení, léčení, alternativní formy setkávání atd.). Zároveň ukazuje různé možnosti a cesty, jak lze žít ,jinak“, odlišně od hlavního proudu, někdy i proti němu, ale především v souladu s vlastními hodnotami. Budu zde analyzovat pohled Pravého domácího časopisu (PDČ), který významným způsobem reflektuje, komunikuje a zároveň utvárí alternativní životní styly a formuje komunitu kolem nich propojenou.

Následující text se věnuje popisu toho, jak jsou alternativní životní styly reprezentované $\mathrm{v}$ alternativním médiu, analýze hodnot, které stojí v pozadí volby těchto životních stylů, a nahlížení na kulturní formaci, kterou časopis reprezentuje i spoluutvárí, pomocí konceptu subkultury kulturních kreativců. Hledám odpověd' na otázku, zda je komunita, která spojuje paletu alternativních životních stylů a hodnot reprezentovaných v Pravém domácím časopisu, projevem kulturního kreativismu a z jakých důvodů. 


\section{Teoretické uchopení: subkultury a životní styly}

Subkultury se v sociálních vědách zkoumaly různými způsoby a s odlišným akcentem na charakteristiku skupin, hodnot a životních stylů. Zatímco Chicagská škola se ve 20. letech 20. století zaměřila na městskou podtř́ídu bohémů a tuláků, Birminghamská škola kulturních studií v 70 . letech zkoumala subkultury mládeže jako vyjádření kultury dělnické tř́ídy. Sub-kultura se obecně chápe jako podkategorie kultury (Gordon 1997) a svým vymezením v realitě se blíží pojmům komunita či skupina. Sarah Thorntonová považuje subkultury za „skupiny lidí, kteří mají něco společného (např́íklad sdílejí problém, zájem, činnost), což je odlišuje významně od členů jiných sociálních skupin“ (Thornton 1997: 1). Subkulturu můžeme chápat také jako volbu životního stylu. Podle Johna Irwina je subkultura „sociální svět, sdílená perspektiva“ těch, kteří žijí podobným způsobem (Irwin 1997: 67). V pojetí Duffkové a kol. lze na subkultury nahlížet jako na skupiny spojené kolem životního stylu určitého segmentu populace definovaného např́íklad profesí, etnicitou či volnočasovými aktivitami (Duffková - Urban - Dubský 2008).

Koncept subkultury v současné společnosti považují někteří za nadbytečný, nebot' se setkáváme s vysokou variabilitou kulturních stylů a identit. Dřivější opozice dominantní kultury a subkultury se vytratila, protože kultura se rozpadla na pluralitu životních vkusů, vyznačuje se diverzitou a mísením mnoha stylů (Chaney 2004). Pod vlivem postmoderny v kultuře se uvažuje o tzv. postsubkulturách (Muggleton 2000), či o tom, co přichází „po subkultuře" (Bennett - Kahn-Harris 2004), at' už to jsou scény, kmeny, komunity založené na vkusu či životní styly. Postmoderní subkulturní identity jsou mnohočetné a fluidní a konstruují se na základě spotřeby. V postsubkulturách se dává přednost individualismu před kolektivismem, heterogenitě před konformitou a karnevalu před zájmem o politiku (Muggleton 2000).

Michel Maffesoli (1996) přišel s hypotézou tribalismu, která předpokládá, že se v současné společnosti utvářejí nové kmeny (neo-tribes) dočasně spojované na základě emočních vazeb a charakterizované touhou po ztrátě individuality v kolektivu. Kmeny jsou malé skupiny, jejichž hlavním cílem je setkávání práatel, vzájemná pomoc a družnost, mezi nimiž se mohou lidé volně pohybovat. Lze tak pozorovat mnohočetnou existenci rozptýlených skupin, jejichž jediným účelem je sdílet citové „teplo“. Soudržnost kmenů umožňuje sdílení pocitů a vkusu jednotlivých členů, at' se jedná o zaměření kulturní, sportovní, náboženské či sexuální. Paradigmatu tribalismu je naprosto cizí individualistická logika, neidentifikuje se s žádným politickým projektem a zajímá ho kolektivní přítomnost. Proto jsou pro něj dủležité každodenní rituály a vrací se význam festivalů a karnevalů. 
V textu budu pracovat i s pojmem alternativní životní styl (Duffková 2006; Duffková - Urban - Dubský 2008), vzhledem k tomu, že jde o „in-vivo kód“ neboli pojem, který sami aktéři používají. Alternativní životní styl se odlišuje v hlavních složkách životního stylu (bydlení, strava, práce, spotřeba, zábava atd.) od konvenčního životního stylu a zakládá se na existenci možnosti volby mezi různými životními styly. K alternativnímu životnímu stylu se člověk rozhoduje dobrovolně na základě subjektivní volby dané hodnotovými orientacemi jedince.

Vzhledem k tomu, že alternativní životní styl sice naznačuje pozici ve společnosti, která spočívá v odlišnosti od hlavního kulturního proudu, je potřeba specifikovat, o jaký obsah alternativy se jedná. Alternativa se používá k označení různých jevů, např́íklad neoficiální kultury a okrajové hudební scény během normalizace (viz Alan a kol. 2001). Proto považuji za důležité vymezit obsahovou náplň a zaměření alternativy. $\mathrm{K}$ tomu budu používat perspektivu subkultury kulturních kreativců, která se prozatím nestala součástí diskurzu subkulturních a postsubkulturních studií a vychází spíše z konceptů kontrakultury, nových sociálních hnutí a nových náboženských hnutí.

\section{Subkultura kulturních kreativců}

Koncept subkultury kulturních kreativců byl vyvinut americkými sociology Paulem Rayem a Sherry Andersonovou na základě rozsáhlého výzkumu hodnot a životních stylů prováděného od poloviny 80 . let do konce let devadesátých, ve kterém využívali data z dotazníkových šetření se vzorkem 100 tisíc Američanů, stovek fokusních skupin a 60 hloubkových rozhovorů (Ray - Anderson 2000). Kulturní kreativce chápou jako propojení nových sociálních hnutí (ženských, etnických a environmentálních) a nových náboženských a spirituálních hnutí, která se rozvinula z kontrakultury 60 . let. Autoři zdokumentovali výraznou změnu v hodnotách a světonázoru u velké části Američanů, podle nich se jedná o $26 \%$ populace USA, tedy až 50 milionů obyvatel. Subkultura - či spíše segment společnosti - kulturních kreativců je tak početná, nebot' kromě vůdců a aktivistů zahrnuje i př́iznivce a sympatizanty několika generací u velké řady hnutí. Kulturní kreativce charakterizují silné environmentální hodnoty, podpora míru, ženských a dětských práv, ale i orientace na seberealizaci, budování pečujících vztahů, alternativní spiritualitu, alternativní léčení a osobní rozvoj. Kulturní kreativci odmítají materialismus a egoismus, společenské nerovnosti a jsou kritičtí vůči korporacím, vládě a konzervativcům. Autoři tuto subkulturu vymezují vưči dalším dvěma velkým segmentům americké společnosti modernistům a tradicionalistům. 
Kulturní kreativci prosazují pozitivní vizi udržitelné budoucnosti, chtějí žít v harmonii se Zemí a hlásí se k ekologické a sociální zodpovědnosti. Jsou nejvýraznějšími názorovými vůdci v oblasti environmentálních postojủ. Ekologické hodnoty jsou u nich ovšem rámovány spiritualitou nebo šířeji proměnou vědomí a kulturním probuzením, zejména pro jádro kulturních kreativců jsou témata vědomí a sociálních otázek prolnuta a př́rodu považují za posvátnou.

Kulturní kreativci kladou důraz na autenticitu a dbají na to, aby jejich aktivity byly konzistentní s tím, v co věří a prosazují. Inspirují se osobními př́běhy a propojují akcent na osobní zkušenost s globálním pohledem na planetu. V subkultuře se výrazně projevuje ženský prvek, a to jak na úrovni hodnot, tak i z hlediska participace, jelikož to jsou ženy, kdo v subkultuře převažují, je jich zhruba $60 \%$. Zejména v jádru subkultury, které tvoří spisovatelé, umělci, psychoterapeuti, léčitelé, environmentalisté a kulturní feministky, u kterých se silněji projevují environmentální hodnoty a význam osobního růstu a spirituality, je poměr žen $\mathrm{k}$ mužům $2: 1$. Z hlediska věku, rasy a socioekonomického statusu se dá subkultura považovat za heterogenní.

U kulturních kreativců autoři vysledovali proces změny vědomí, uvědomění si globálních problémů a propojenosti světa, a navazující změny života, jak vnějšího, směřujícího ke smysluplné práci, dobrovolnictví či udržitelné spotřebě, tak i vnitřního ve formě rozvíjení lidského potenciálu. Kulturní kreativci podle nich překračují dichotomii alternativní spirituality zaměřené na vnitřní změnu a politického aktivismu, který má za cíl zachránit svět vnější. Chtějí vytvářet integrální kulturu osobního i společenského, přemostují tradice Východu a Západu a prosazují ženský pohled na svět, aby ho propojili s dominantním mužským.

\section{Kulturní kreativci v Česku: stav zkoumání}

Koncept kulturních kreativců nebyl v českém prostředí při zkoumání (sub)kultur, alternativních hodnot a životních stylů spojujících zájem o životní prostředí, ženskou tematiku a spiritualitu prozatím výrazně uplatňován. ${ }^{1}$ Výjimku tvoří článek Ireny Kašparové (2017) o domácím vzdělávání jako o výrazu kulturního kreativismu.

Samotný pojem ve zkoumaném prostředí rezonuje. Už v prvním čísle odkazuje Pravý domácí časopis na projekt Učíme se př́iběhy, ${ }^{2} \mathrm{v}$ rámci kterého vznikl v roce 2013 i dokumentární film „Žít změnu“ režiséra

\footnotetext{
1 Dosavadní české studie o subkulturách se věnují většinou hudebním subkulturám mládeže (např. Kolářová 2011; Daniel 2016; Charvát - Kuř́ík 2018).

2 www.ucimesepribehy.cz
} 
Václava Kučery, inspirovaný kulturními kreativci v západní Evropě a USA, a přebírá z něj některé prríběhy. Také se přímo vztahuje k sociologickému konceptu kulturních kreativců a dává ho do lokálních souvislostí (5/2017: 4-37).

Pokud uvažujeme o konvergenci hnutí, kontrakultur a životních stylů, lze konstatovat, že tyto jevy byly u nás zkoumány spíše odděleně. V Česku se rozvíjel výzkum orientovaný na environmentální sociální hnutí, ale hlavně z perspektivy organizací sociálních hnutí a protestních událostí a taktik (např. Binka 2010; Fagan 2004; Novák 2017). Stejně tak se environmentálně př́znivý životní styl stal předmětem řady studií, zejména ve spojitosti s dobrovolnou skromností, ekologickým luxusem a generačním přenosem skromného života (Librová 1994; 2003; Librová et al. 2016; Kala - Galčanová - Pelikán 2017). Hana Librová (2016: 264) poukazuje na to, že environmentálně př́íznivý životní způsob zkoumaných Čechů byl intuitivní a účastníci výzkumu („pestř̌i“) nemohou být spojováni s žádným hnutím. Tento argument neidentifikace s širšími kolektivitami vychází u Librové také z konstrukce výzkumného vzorku na základě dobrovolné skromnosti původně z roku 1992, tedy z doby, kdy se české prostředí začalo teprve otevírat zahraničním vlivům v podobě hnutí a subkultur.

Vedle toho se u nás rozvíjí studium nových náboženských hnutí a alternativní spirituality (např. Vojtíšek 2007; Nešpor - Václavík 2008; Ondrašinová 2010). Ekologii a spiritualitu propojují výzkumy Dušana Lužného (2004), který se však zaměřuje na zkoumání konkrétních nových náboženských hnutí, jako je Hare Kršna nebo buddhismus, a jejich vztahu k otázkám životního prostředí. Autoři zabývající se novými náboženskými hnutími a alternativní spiritualitou, jež jsou ovlivněné jak východními náboženstvími, tak i spiritualitou př́rodních národů a pohanstvím, dávají jejich vznik do souvislosti s kontrakulturou 60 . let, která směřovala svou kritiku vůči západní technokratické společnosti a požadovala radikální změnu vědomí a kultury (Roszak 2016). Vznik novějších hnutí a dalších forem př́rodní spirituality sleduje Jiřina Kramosilová (2009) na př́kladu ekokomunitního hnutí a zakládání rodových statků v Rusku v románech Vladimíra Megreho Zvonící cedry.

V tomto textu chci přinést pohled, který tematizuje alternativní životní styly, které obsahují jednak ekologické hodnoty a vyznačují se šetrností $\mathrm{k}$ př́rodě, ale zároveň je pro ně významná i alternativní spiritualita či ženská tematika, která se projevuje např́klad v nových rodičovských stylech. Chci uvažovat o konvergenci životních stylů, kontrakultur a hnutí životního stylu (lifestyle movements; Haenfler - Johnson - Jones 2012) a dívat se na ni optikou konceptu kulturních kreativců. 


\section{Metoda výzkumu}

Analýza je součástí širšího projektu, který se věnuje hnutím životního stylu a konkrétním projevům v životních stylech, jež propagují (např. permakultura, hnutí návratu k půdě, hnutí potravinové suverenity, bezodpadové hnutí). Ve výzkumu postupuji několika metodami. Využívám jednak analýzu médií, dále etnografii a pozorování a provádím hloubkové rozhovory s představiteli jednotlivých hnutí. Pro účely tohoto textu jsem vybrala pouze výseč jak tematickou, tak metodologickou, a to mediální zobrazení alternativních životních stylů v tištěném médiu. Pro analýzu jsem zvolila Pravý domácí časopis, a to jednak z důvodu, že jako jeden z mála píše o výše zmíněných hnutích životního stylu a představuje významného prostředníka pro propagaci alternativních hodnot a životních stylů. $\mathrm{Z}$ tohoto hlediska by bylo možné se zaměřit také na jiné časopisy, které tematizují alternativní životní styl, např́́klad Regeneraci nebo Regenu, ale tato média mají centrální téma zdraví a alternativní léčení a ostatním aspektům životního stylu se věnují okrajově. ${ }^{3}$ Druhým důvodem pro výběr bylo, že jsem na základě pozorování v terénu zjistila, že PDČ je čten v různých alternativních kruzích a že lidé, které jsem během pohybu v terénu poznala, do něj i sami přispívají nebo s nimi redaktoři dělají rozhovory. PDČ je nezávislé médium, které vytvář́ autorský pár a na ně napojený kolektiv, vychází od roku 2013 jako tištěný měsíčník v současném nákladu 11860 výtisků a má 4300 předplatitelů. Prozkoumala jsem celé obsahy všech čísel od začátku roku 2013 do května 2017 (45 čísel, celkem 2612 stran) a tuto datovou základnu jsem doplnila o analýzu rozhovoru s šéfredaktorkou časopisu, který jsem vedla v dubnu 2018, a záznamu rozhovoru s šéfredaktorkou v DVTV 4. 9. 2017. Pro zpracování dat jsem použila metodu kvalitativní analýzy médií podle Altheida (1996), která odkrývá vzorce a vztahy v procesu dokumentování porozumění komunikaci významu. Analýza vede k vytváření kategorií procesy neustálého objevování a neustálé komparace situací, stylů a významů. Na základě čtení všech materiálů jsem vytvářela kódy a kategorie a okódovala segmenty, které se k daným kódům vztahovaly, dále jsem identifikovala vztahy mezi kódy a dimenze jednotlivých kategorií. Protokol jsem vytvářela pomocí programu na zpracování kvalitativních dat MaxQDA.

V následujícím textu budu postupovat nejprve zdola, od empirického materiálu, a předkládat to, co jsem našla v samotných datech, a následně srovnávat empirii s konceptem kulturního kreativismu.

3 O vztahu k ženským časopisům mluvím dále v kapitole „Pravý domácí časopis ve světle kulturního kreativismu“. 


\section{Analýza dat: Alternativní životní styly v Pravém domácím časopisu}

Pravý domácí časopis se na jaře roku 2013 zničehonic objevil na pultu zdravé výživy, kam jsem chodila s dětmi nakupovat biopotraviny a rostlinné produkty. Zaujal mě podtitulem „Časopis o všem, co je skutečné“, výčtem témat na obálce (Bydlení-Zahrada-Rodina-Vaření-Př́roda-Charita-Ekologie-Fairtrade-Soběstačnost-Biopotraviny-Farmářské trhy-Alternativní léčba-Řemesla a vyrábění), jakož i obrázkem mladé rodiny s dětmi zavěšenými v šátcích na titulní straně. Uvnitř jsem našla řadu témat, která mě jako matku malých dětí se zájmem o zdravý a udržitelný život zajímala: látkové pleny, lesní školky, permakultura, kompostování, vaření z bylin a divokých rostlin, kritika cukru atd. Dokonce jsem se v něm sama našla na fotografii publika na konferenci Aktivní rodičovství, konané v Brně v roce 2011. Následující čísla časopisu jsem si nenechala ujít a bavila jsem se o něm s kamarádkami, matkami na rodičovské dovolené, které ho také četly. Bylo možné ho také sdílet v místním komunitním centru, kde jsme se scházely.

Pravý domácí časopis pokrývá řadu témat, která můžeme rozdělit do tematických bloků. Často se zabývá bydlením, a to zejména ve formě tzv. př́rodního stavitelství, věnuje se tématu stavění ekologických domů z lokálních a obnovitelných materiálů, jako je sláma a hlína. Sleduje př́běhy těch, kteří žijí celoročně v maringotkách nebo jurtách, těch, kteří recyklují vodu i odpady, pořizují si kompostovací záchod nebo čistí vodu v kořenové čističce. Píše o lidech, kteří se odstěhovali z města na venkov s motivem být blíže př́rodě a hospodařit na svém kousku půdy. Zahradničení se tu nese v duchu tvorby př́rodních, permakulturních či rodových zahrad, které respektují prrírodní procesy a cykly. Časopis ukazuje, že místo chlorovaných bazénů si lidé pořizují př́rodní jezírka, obracejí se k sázení starých odrůd stromů, pěstují léčivé byliny, biozeleninu a ovoce pro vlastní potřebu a některé druhy plodin sami semenař́.

PDČ se intenzivně věnuje tématu potravin a vaření. Prezentuje řadu trendů alternativních forem stravování, vedle vegetariánství dostává prostor veganství, makrobiotika, vitariánství (raw strava) či sběr a př́prava jídla z divokých rostlin. Důraz je kladen na konzumaci biopotravin, čerstvých, nejlépe doma vypěstovaných surovin, zdravé stravování s vypuštěním nezdravých složek a návrat k domácímu vaření. Vedle zdravých receptů se v časopisu dozvíme, jak se dá ekologicky pečovat o domácnost a tělo, a najdeme tu recepty na domácí výrobu čisticích prostředků či př́rodní kosmetiky.

Tématem, které tvoří stabilně obsah časopisu, je i alternativní léčení. Setkáme se tu s př́běhy lidí, kteří se uzdravili pomocí alternativních terapií, i s názory expertů z celé škály alternativní medicíny (celostní, tradiční 
čínská, psychosomatická, homeopatická či ájurvédská medicína), stejně jako s recepty na domácí léčení pomocí prostředků z prrírody. Velkou část časopisu zaplňují články o rodičovství, které je rámováno jako vědomé, aktivní, kontaktní či alternativní, s tématy jako domácí porody, (ne)očkování, používání látkových plen, nošení dětí v šátku, alternativní či domácí vzdělávání.

V tomto médiu je silně patrný návrat k oblibě tradičních řemesel a ručních prací, dozvíme se tu např́íklad o plstění ovčí vlny, řezbářství, výrobě šperků či různých tradičních formách zpracování potravin. Nedílnou součástí časopisu jsou různé návody na to, jak si doma něco vyrobit (např́íklad bosoboty či domácí kváskový chléb).

Prostřednictvím osobních př́běhů se na stránky časopisu dostávají také rozličné formy spirituality (často pohanství, slovanství, ženské kruhy, tantra) a alternativní praktiky inspirované neevropskými kulturami (jóga, tai chi, šamanismus), ale vlivné je tu i křestanství nejen přes waldorfské školství a biodynamické zemědělství. Na své si přijdou také čtenáři, kteří hledají osobní, církví nezprostředkovaný vztah k posvátnu. Mohou se seznámit s různými metodami zkoumání vědomí, jako jsou meditace, regresní terapie či holotropní dýchání. Pravý domácí časopis se významně věnuje tématům spojeným s osobním rozvojem. V časopisu mají prostor i různé charitativní a dobrovolnické programy a kampaně (Pěstuj planetu, Change your shoes apod.).

\section{Složky a kombinace alternativního životního stylu}

Mohli bychom sice pokračovat $\mathrm{v}$ detailnějším rozboru témat, ale $\mathrm{z}$ dat vystupuje jedna kvalita, která stojí za pozornost: prolínání a kombinování jednotlivých aspektů životních stylů, které lze propojovat a aktivování jednoho může navést k praktikování dalšího. Četba časopisu sama o sobě může podnítit k rozšíření palety praxe alternativního životního stylu, jak ukazují některé prríspěvky od čtenářů, kteří časopisu děkují za inspiraci pro svůj život.

Neznamená to, že všichni, kdo časopis píší nebo o jejichž životním stylu vypovídá, praktikují všechny složky alternativního životního stylu ve všech oblastech. Jsou ovšem tací, kteří ve svém životě dokázali integrovat řadu jednotlivých elementů:

Permakulturisté dobře zapadají do škatulky toho, čemu se obvykle ř́ká „alternativici: žiji skromně, co nejvíc v souladu s prírodou, která pro nè mívá i spirituální náboj. Často se cítí duševně spř̀znèní s makrobiotiky (ačkoli sami nemusí být vegetariány), s príurženci domácích 
porodů, slidmi kř́sícími tradiční, polozapomenutá vesnická řemesla, s léciteli využívajícími alternativní postupy, s novopohanským a New Age hnutím, sbylinkárí a podobně. Opticky patři mezi „batikované. Také kladou velký di̊raz na budování místnich komunit, vytvárení síti vztahů, na spolupráci a soběstačnost v rámci malých skupin. (1/2013: 38)

Rodiny, které dokázaly propojit řadu prvků ve smysluplný celek, jsou známé čtenářům časopisu a fungují jako vzor, popř́padě radí ostatním „jak na to“. Př́́kladem je rodina, která propaguje kontaktní rodičovství a k prŕrodě šetrný životní styl:

(...) dcery nenosily díky bezplenkové komunikační metodě pleny, víc než v kočárku byly v šátku u mámy nebo u táty, nejsou očkované, nechodí pravidelně k lékaři, protože nemoci řeši tahle rodina primárně homeopaticky. (...) nakupují zdravé a lokální potraviny, používaji ekologickou drogerii a př́rodní kosmetiku. Už několik let nemají televizi ani ledničku. Na Vysočině staví svépomocí slaměný di̊m a zakládají permakulturní zahradu. (1/2013: 5)

Z jednotlivých př́běhů lze vysledovat, že jedinci se většinou nezajímají od začátku o všechny rozměry alternativního životního stylu. Spíše jde o posloupnost - nejprve zařadí jeden prvek a díky němu se dostanou $\mathrm{k}$ dalšímu. U jednotlivců a rodin nenajdeme stejný počet prvků, ani stejnou následnost, ale často bývá prvním motivem narození dětí:

Po proním domácím porodu a zkušenostech s domorodou dcerkou Viktorkou jsme dospěli rozhodnutí, že se odstěhujeme z mësta na venkov. Poř́dili jsme si tedy v Podkrkonoší starou chalupu a během dalšich několika let v ní přivedli na svět ještě tři děti. (7/2014: 9)

\section{Konstrukce alternativnosti}

Alternativnost je konstruovaný a vyjednávaný terén. Má své hranice, které se mění podle pozice, kterou člověk zaujímá, a má určité stupně a kombinace - některá složka zasahuje do mainstreamu, jiná se vyznačuje větší či menší alternativností. Sama šéfredaktorka PDČ se ve svých editorialech často zabývá definicí alternativy a otázkou, zda ona sama a její rodina působí alternativně a v jakém smyslu: 
Spousta lidí si o mně myslí, že jsem „alternationí. Teda, abych byla presná. Spousta lidí, kteř́ jsou z mého pohledu takový středostavovský konzumni mainstream, si to o mněmyslí. A ti, kteří jsou zase alternativní z mého pohledu, jsou naopak často překvapeni mým bezbřehým středostavovstvím a alternativní nedisciplinovaností. (2/2017: 1)

Ona sama se např́klad snaží vařit zdravě a z lokálních zdrojů, ale někdy se jí to z časových nebo jiných důvodů nepodaří a alternativnímu okolí je nucena vysvětlovat, proč se provinila vůči společným hodnotám.

Alternativa jako možnost volby nutně vede $\mathrm{k}$ tomu, že se vztahuje určitým způsobem k okolí. Být alternativní je tak popisováno jako „nejít s davem“, „odchylovat se od mainstreamu“. K tomu, aby člověk byl svým okolím brán i ve své alternativnosti vážně, je však potřeba nepřecházet do extrému:

My nechodíme v pytlích a nežijeme v jeskyni, takže na nás okolí reaguje tolerantně a dobře. Navíc, pro měje životním posláním šírit informace o kontaktním rodičovství a šetrnèjším, trvale udržitelném životním stylu, a tak je pro mě přirozené, že podle toho $i$ žiju (...) Určitè nejdeme s davem, ale rozhodujeme se podle získaných informací z různých zdrojů a také podle naši intuice. A za svá rozhodnutí pak prebíráme plnou zodpovèdnost. Pro někoho může být takové chování alternativní, já ho ale vidím jako normální. Normou by, podle mè, mèlo být, že se člověk rozhoduje individuálně a svobodně. (1/2013: 5)

Lidé v časopisu považují svůj životní styl za rozumný a chtějí, aby nebyl vnímán jako abnormalita. PDČ a lidé, kterým dává prostor, se snaží neuzavírat do exkluzivních komunit, ale jejich zájmem je rozšíření alternativních životních stylů do většinové kultury. Např́klad expertka na výživu Margit Slimáková, vegetariánka, která propaguje zdravý životní styl, v konceptu Zdravého talíře doporučuje maso. Chce totiž ovlivňovat co nejširšsí populaci: Být „alternativec", tak si všude zavírám dveře. (3/2014: 5)

Snahy o mainstreamizaci alternativních témat se v určitých ohledech dař́, např́klad Hanka Zemanová, autorka biokuchařek, v časopisu poukazuje na to, že zatímco před 20 lety bylo bio neznámým pojmem a nabídka biopotravin se téměř rovnala nule, dnes už témata ekologického zemědělství a biopotravin pronikla do povědomí širší veřejnosti, i když ten proces nebyl prostý překážek a překonávání předsudků. Podobné trendy lze vysledovat i v jiných oblastech, např́íklad rozšíření diskuse o domácích porodech a domácím vzdělávání. 


\section{Hodnoty a principy spojující životní styly}

Co spojuje různorodé životní styly kromě jinakosti, postavení vůči mainstreamu a prozatímní marginální pozici alternativních stylů na mapě způsobů života u nás? Existuje nějaký klíč k pochopení toho, proč třeba vegetarián neočkuje svoje děti a začne si doma šít bosoboty? Za konkrétními projevy životních stylů jsem hledala to, co není na první pohled tolik evidentní: co propojuje jednotlivé př́běhy, různorodé životní styly, co stojí za tím, že se člověk rozhodne pro změnu životního stylu. Motivem a pojítkem, proč žít alternativně, jsou hodnoty, jednotící principy a př́ístup $\mathrm{k}$ životu, které redakce, širší okruh přispěvatelů a také lidé, o kterých se píše a kterým je v časopisu nasloucháno, vyznávají. Hodnoty a přístup k životu, které jsem v PDČ vysledovala, jsem rozdělila do tř́ bloků: 1 . Obrat k prŕrodě a přirozenosti, 2. Svoboda a autonomie 3 . Změna vědomí.

1. První hodnotu naznačuje silný vztah $\mathrm{k}$ př́rodě, touha po přirozenosti, potřeba umožnit sobě i dětem kontakt $s$ př́írodou a snaha o zlepšení životního prostředí, která souvisí s péčí o zdraví své a svých dětí. Tuto hodnotu bych celkově nazvala ne návrat, protože ten již není možný v rozsahu, jak se žilo dříve, ale „obrat k prrírodě a přirozenosti“. Cílem je žít „ve svobodě, v jednoduchosti, v prírodě" (4/2015: 32). Zájem o př́rodu a udržitelnost se manifestuje $\mathrm{v}$ zaměření časopisu na biozemědělství a biopotraviny, př́rodní stavitelství a zahradničení, vlastní produkci potravin či život bez odpadu, zatímco obrat k „přirozenosti“ u léčení, neočkování, domácích porodů, výchovných stylů atd.

2. Hodnota svobody se chápe spíše jako autonomie jedince v životních volbách, osvobození od institucí, vlivu státu i korporací na individuální způsob života. Svoboda se tak vnímá jako nezávislost, zodpovědnost za sebe a víra v tvořivost i moc individua měnit skrze změnu vlastního života společnost. Jednoduchý život v jurtách, maringotkách a přírodních svépomocných domcích je prezentován jako vzor, který vrchovatě naplňuje ideály svobody a kontaktu s př́rodou současně. V jednoduchých obydlích je člověk nezávislý na sítích a dodávkách energií, může si pěstovat vlastní potraviny a cítit se tak skutečně svobodný. Autonomie a nezávislost nachází konkrétní projev ve snahách o soběstačnost a v široké paletě kutilské či do-it-yourself (DIY) praxe: samozásobitelství, stavění svépomocí, vyrábění domácí kosmetiky, ale přeneseně i v domácích porodech a domácím vzdělávání. 
3. Změna vědomí není snad hodnota, ale př́stup k životu, nezbytná podmínka pro porozumění světu a proměnu životního stylu. Projevuje se jednak na úrovni individuální spirituality (v různých formách, které si jedinec sám vybírá a propojuje do smysluplného celku), ale také obecněji znamená vědomý a reflektivní př́stup k životu, zájem o kořeny společenských problémů a promýšlení globálních souvislostí vlastního života. Není to ale jen racionální př́stup, stejně silně se uplatňují emoce, intuice a př́stup k životu „srdcem“. Att už jde o doslova vědomé vaření, vědomé ženství a rodičovství, vědomou pedagogiku či vědomou chůzi, znamená to uvědomění si procesu daného jevu a jeho důsledků pro tělo, mysl, vlastní život i okolí, dávání věcí do souvislostí a žití v přítomném okamžiku. Vědomý př́stup k životu také proti teoriím staví vlastní př́mou zkušenost.

Řada příběhů v časopisu vypovídá o spojení s něčím větším, než je jedinec i společnost, s transcendentnem, at má jakoukoli formu (mluví se tu o bohu, vesmíru či kosmické energii). K tomuto vnímání světa se hlásí $\mathrm{i}$ šéfredaktorka časopisu $\mathrm{v}$ našem rozhovoru:

\begin{abstract}
„O sobě ř́kám, jsem majitelka hlavy, kterou prošel nápad na Pravý domácí časopis. Protože taky nemám moc pocit, že bych ho vymyslela a už vưbec ne, že bych ho ř́dila. Skrze mè je vymyšleno, skrze měje rízeno. Takový je i můj vztah ke spiritualitě. Věrím v sílu myšlenky. Věrím v to, že si suět dělám takový, jak ho vnímám, tak on takový opravdu je."
\end{abstract}

Šéfredaktorka zároveň pozoruje ve společnosti rozšiřování vědomí a postupnou akceptaci dříve okrajových názorů a praxe.

$\mathrm{V}$ tomto smyslu se dá propojit i změna vědomí s hodnotou autonomie a vlastní zodpovědnosti. Pokud se lidé okolo PDČ napojují na autoritu vyšší, než je světská politická vláda, pokud ve svém jednání následují božský nebo kosmický princip, tak vliv společnosti se svými institucemi a zákony vnímají jako slabý, popř́padě jako omezující.

Soužití s př́rodou je nahlíženo v širším kontextu a do diskurzu PDČ zapadá vnímání přrírody nejen jako zásobárny zdrojů pro člověka, ale jako domova, o který je potřeba pečovat, nebo jako Matky Země, kterou je potřeba ochraňovat. Následující vysvětlení změny vlastního života směrem k udržitelnosti je součástí světonázoru řady (i když určitě ne všech) lidí kolem PDČ: 


\section{„Č́m dál víc vnímám Zemi jako Matku a chci a potrébuji s ní zưstat $v$ kontaktu. Proto se snažím - v rámci možností a momentálního množstuí vlastní energie - pro ni činit to dobré." (4/2017: 52)}

Na základě rozboru hodnot mohu prohlásit, že hodnoty, zejména ty environmentální a spirituální, které jsem nalezla v Pravém domácího časopisu, naplňují koncept kulturního kreativismu. V českém prostředí se navíc silně projevuje důraz na svobodu, autonomii a soběstačnost, který Ray s Andersonovou v USA nezdůrazňují. Nicméně v základu subkultury kulturních kreativců stála americká kontrakultura 60. let, pro kterou přesně tyto hodnoty hrály stěžejní roli (srv. Roszak 2016).

\section{Další rozměry kulturního kreativismu}

Pohled přes teoretickou mřížku kulturního kreativismu použiji ještě u dalších témat, jako je ženský aspekt, př́iběhy, kritika vlády a korporací a kolektivní identita.

V subkultuře kulturních kreativců převažují ženy, stejně tak Pravý domácí časopis vypadá jako ženský projekt: šéfredaktorkou je žena, redakční kolektiv tvoř́ ženy, většina článků pochází od žen. V časopisu se objevují recepty na vaření, výrobu kosmetiky či návody na ruční práce, tedy takzvaná ženská témata. Přesto si troufám tvrdit, že PDČ není klasický ženský časopis. Je to časopis „pravý domácí“, vypovídající o světě z perspektivy každodennosti, domova, rodiny a komunit, kde muži mají svou nezastupitelnou roli a také jsou do tohoto prostoru zváni a je jim z hlediska těchto témat nasloucháno. Muži, kteří časopis spoluutvářejí, jako například grafik, fotograf či autoři textů, jsou manželé nebo partneři redaktorek, kromě toho se ale v časopisu prosazují hlasy dalších mužů, např́íklad otců na rodičovské dovolené, expertů na osobní rozvoj, veganských kuchařu, ale hlavní mužskou doménou je svépomocné přírodní stavění a do značné míry i permakulturní zahradničení. Muži jsou na cestě rámované obratem k prŕrodě, vlastní zodpovědností a DIY praxí ceněnými partnery. Rodina a život, tedy hodnoty zdánlivě ženské, se podle časopisu týkají i mužů. Je oceňováno, když se muži účastní porodů nebo zůstanou na rodičovské dovolené s dětmi, když se stanou aktivními otci nebo svépomocnými staviteli. Muži jsou vtahováni z oblasti politiky a byznysu zpět do domácnosti a pospolitosti.

Př́běhy zásadní životní změny směrem k alternativnímu životnímu stylu jsou vykreslovány jak u mužů, tak u žen. Pro ženu často určuje obrat $\mathrm{k}$ prrírodě období těhotenství, porodu a péče o dítě. Matky prezentované na stránkách časopisu se snaží o přirozený a zdravý průběh těhotenství 
a porodu, bez vnějších zásahů „civilizace“. Typické je u nich dlouhé kojení, biovaření pro rodinu či přechod na látkové pleny. Na mateřské a rodičovské dovolené se tyto ženy začnou zajímat o další souvislosti jako je např́klad očkování, ekologická hygiena a péče o domácnost nebo alternativní formy vzdělávání. Některé se odvrátí od svého původního zaměstnání, typicky v „korporátu“, a začnou se realizovat v oblasti alternativního podnikání (šití látkových plen, různé formy terapií a cvičení apod.). Díky vyvázání se ze „systému“ odchodem na mateřskou a rodičovskou dovolenou a vyhledávání společenství podobně orientovaných maminek přicházejí do kontaktu i s dalšími aspekty alternativního života.

Ve fascinaci osobními príběhy nacházím stoprocentní paralelu se světem amerických kulturních kreativců. V časopisu se skrze obyčejné i neobyčejné př́běhy lidí nazírají různá témata, at je to ekologická produkce květin, lokální výroba bot nebo třeba vaginální mapování.

Stejně tak se tu objevuje kritika korporací a společenských institucí, nikoli však politiky jako takové. Časopis se dle slov šéfredaktorky neorientuje na politická témata, jejich cílem je předkládat pozitivní př́klady lidí, kteř́ žijí alternativně a v souladu s př́rodou (rozhovor pro DVTV). Šéfredaktorka nemá chut' kritizovat politiky, ale snaží se začít u sebe, měnit své okolí a ke změně inspirovat i širší publikum. Kritika společnosti není hlavní náplní časopisu, ale občas probleskne, zejména jako zarámování problému a zdůvodnění volby alternativního života. Kritika nikdy nevyznívá samoúčelně, naopak je cestou $\mathrm{k}$ formulaci pozitivních vizí a hledání praktických řešení. Nejsilněji se v časopisu prosazuje kritika odcizení lidí od př́rody, jejího znečištování a ničení. Zaměřuje se i na konzumní život podporovaný velkými obchodními společnostmi, nadbytek, reklamu a utrácení peněz za zbytné věci. Vedle toho zaznívá kritika uniformity, některých společenských norem a předpisů a zaběhnutých způsobů jednání.

Ačkoli se PDČ obecně staví proti konzumu, nezastírá, že propaguje i komerční věci, které se už staly poměrně slušným byznysem, at' už jde o biopotraviny, alternativní medicínu či kurzy osobního rozvoje. ${ }^{4}$ Pravý domácí časopis obsahuje řadu reklam a přiznává, že podporuje firmy, které s redakcí sdílejí náhled na svět (např. Country Life a další značky zdravých potravin či kosmetiky). Dává tedy prostor zelené spotřebě a zelenému byznysu, na druhé straně tu mají zastoupení hlasy, které obhajují minimalismus a „downshifting“ (zaměření na nižší spotřebu a jednoduchost), a časopis ukazuje také cestu do-it-yourself, vlastního vyrábění a tvoření různých objektů každodenního života.

4 Srovnej s kritikou podnikatelské orientace kontrakultury (Heath - Potter 2012). 


\section{Kolektivní identita a konvergence hnutí}

Kulturní kreativci jsou v USA podle Raye a Andersonové koherentní subkulturou až na to, že postrádají kolektivní identitu a sebepojetí jako skupiny. Zkoumaní jedinci se totiž domnívají, že takto smýšlí jen pár jejich známých, i když se podobné hodnoty dají vysledovat u milionů lidí.

Absenci kolektivní identity nemohu na základě dat v Česku potvrdit, i když má specifické projevy. Kolektivní identita je do určité míry tvořena samotným časopisem, který se snaží různými strategiemi vtáhnout čtenářstvo do dění. Informuje jednak o aktivitách typu sousedské slavnosti a akce Zažít město jinak, píše o komunitních zahradách a komunitách podporujících konkrétního zemědělce (KPZ), zprostředkovává zážitky z řady festivalů a akcí jako např́klad festival Evolution, Bio dožínky či Bio slavnosti, kde se redakce setkává s publikem. PDČ navíc organizuje společné akce se čtenáři (např. férová snídaně, chlebopečení) a sdílí výtvory a zážitky. Uveřejňuje ohlasy čtenářů a vypisuje soutěže (recy věci, bezobalu), zprostředkovává kontakty mezi čtenáři navzájem pomocí různých map (mapa čtenář či slaměných domů) a zve na rozličné kurzy, at' už v oblasti tvoření či osobního rozvoje. Časopis přispívá $\mathrm{k}$ tomu, že se podobně naladění lidé mohou setkávat na různém typu akcí a fyzických míst, ale i virtuálních prostorů na internetu.

Povaha setkávání často odpovídá charakteristice nových kmenů (Maffesoli 1996). Na tento teoretický koncept nás může navést samotné slovo „kmen“ uváděné na titulní stránce časopisu v rámečku nad názvem periodika, který v časopisu naznačuje jednak inspiraci domorodými kulturami a zároveň současné alternativní formy setkávání. V rámci subkultury kulturních kreativců dochází k mnohočetnému setkávání jedinců tváří v tvář ve skupinách různě orientovaných, at už to jsou kurzy na výrobu bosobot nebo rodinné konstelace, kde je tmelem sdílení zkušeností, dovedností a prožitků. Tato setkání jsou z hlediska složení osob nahodilá, vedená zájmem a vkusem, ale zejména u těch zaměřených na osobní rozvoj a alternativní spiritualitu (např. ženské kruhy, tantra, šamanismus, holotropní dýchání) při nich dochází $\mathrm{k}$ anonymnímu sdílení hlubokých pocitů, intimních záležitostí a intenzivních zkušeností. Vedle těchto nových kmenů koexistují lokálně formované komunity relativně trvalejš́ho charakteru, jako jsou komunitní zahrady, KPZky či komunitní centra. Lidé se setkávají i na internetu v rámci specializovaných skupin na sociálních sítích, kde také dochází ke sdílení, vzájemné podpoře a emocionálním vazbám. Jedinci uzavření v domácnostech, často právě matky na rodičovské dovolené, se díky internetu necítí izolovaně ani při praktikování alternativního životního stylu, jak ukazuje Emily Matcharová u amerického hnutí nové 
domesticity, které se projevuje v životních stylech jako je kontaktní rodičovství, odmítání očkování, pěstování bio potravin či návrat k ručním pracím (Matchar 2013).

Podle Raye a Andersonové v USA v 90. letech došlo ke konvergenci řady sociálních a nových náboženských hnutí s kořeny v 60 . letech, která se propojila do velkého proudu kulturní změny. S tím pozorovali i posun od protestu k pozitivní agendě a vizi budoucnosti. U nás od 60. let absentuje tradice západních forem nových sociálních i nových náboženských hnutí. Hnutí zdola byla před sametovou revolucí spojena s antilevicovou orientací a př́íklonem ke křestanství, zatímco americká kontrakultura se od křestanství distancovala a hledala inspiraci ve východních a domorodých náboženstvích.

Oba proudy hnutí se u nás na scénu dostávají až v 90. letech, v postsocialistickém prostředí se ovšem nesbližují tak jako v USA. I když bychom mohli najít několik jedinců, kteří ve svém životě propojili téma politické angažovanosti a spirituální orientace, tak na úrovni skupinové ta spojení spíše chybí. Radikální levice se vyvíjela odlišným směrem než hnutí alternativní spirituality, české feministické hnutí s převažující liberální orientací také nenachází stejnou řeč s feminismem diference, který v posledním desetiletí formuluje ženské hnutí zdola ve formě ženských kruhů a ženské spirituality. U environmentálních aktivistů bychom snad našli více spojnic s udržitelným a eko-spirituálně laděným životním stylem, nicméně, jak ukazuje už Librová (1994), pestř́ se vždy lišili od zelených. Př́rodní spiritualita se dotkla ve formě pohanství či satanismu některých hudebních subkultur mládeže jako je např́klad techno nebo metal (viz Daniel 2017), ale aktivistický proud subkultur orientovaný na antifašismus (Kolářová 2011: 208) se vyhnul hodnotám spojeným s úctou k Matce Zemi. Kulturní kreativci v Česku jsou spíše ovlivněni zahraničními hnutími životního stylu jako je permakultura, bezodpadové hnutí, hnutí rodových statků, kontaktní rodičovství apod. To ovšem neznamená, že bychom tu nenašli hnutí protestní, jsou to především hnutí za přirozené porody a hnutí za svobodnou volbu v očkování (více Hrešanová 2017 a Hasmanová Marhánková 2014).

Velikost subkultury odhaduji velmi zhruba na 15 až 20 tisíc lidí, vzhledem k počtu předplatitelů Pravého domácího časopisu (přes 11 tisíc čtenářů) a např́íklad návštěvnosti pražského festivalu Evolution, kde mívá redakce časopisu svůj stánek a který sdružuje témata „bio styl, zdraví, eco world, alternativu a osobní rozvoj" (přes 16 tisíc lidí na jedné akci, přičemž organizován je dvakrát ročně). 


\section{Závěr}

V tomto textu jsem uvažovala o subkultuře kulturních kreativců jako o sociologické kategorii, která zastřešuje řadu aspektů alternativního životního stylu a alternativních hodnot, ale také propojuje různé skupiny aktérů. I když mě osobně se pojem kulturní kreativci př́liš nelíbí, protože konotuje „kreativce“ v reklamních agenturách a celkově tzv. kreativní třídu (Florida 2002), to znamená pracující v nerutinních tvořivých profesích, tak si troufám říci, že komunita reprezentovaná a utvářená alternativním médiem Pravý domácí časopis naplňuje řadu charakteristik kulturního kreativismu. Stránky PDČ nám odkrývají svět praktické ekologie, spirituality, ženských otázek, směřování k tomu, co je autentické a „pravé domácí“, vnímání světa pomocí př́íběhů a snahu o změnu životních stylů směrem k udržitelnosti, tedy klíčové charakteristiky subkultury kulturních kreativců. Jednotlivé roviny životních stylů spojují hodnoty a přístupy, kterými jsou především obrat k prrírodě a snaha o přirozenost společně s hodnotou individuální svobody ve smyslu autonomie jedince a změna vědomí v duchu osobního rozvoje. Ekologické a spirituální hodnoty odpovídají americkému modelu, spiritualita tu ovšem necharakterizuje celou subkulturu, proto mluvím šířeji o změně vědomí, tedy uvědomění si globálních souvislostí pro změnu životního stylu. Spirituální orientace se u amerických kulturních kreativců týká také především jádra subkultury. V Česku je navíc akcentována hodnota svobody a autonomie, tedy v podstatě mainstreamové hodnoty vzývané zejména po sametové revoluci. V USA nejsou tyto hodnoty u kulturních kreativců zdůrazňované, a to zřejmě proto, že jsou základem hnutí a subkultur už od dob americké kontrakultury 60. let. Ray a Andersonová ostatně rozlišují dvě generace kulturních kreativců, pro tu první (v 60 . a 70. letech) byla významná nezávislost, individuální cesta a důraz na ego, zatímco v druhé generaci (80. a 90. léta) se kladl důraz na budování komunit, práci pro společné dobro a šetrnost k Zemi. V první generaci byli političtí aktivisté odděleni od těch, co se věnovali spiritualitě, ale na konci tisíciletí se různé vlivy a hnutí propojují a vytvářejí velký proud kulturní změny. Zůstává otázkou, jestli k podobnému trendu konvergence dojde i u nás. Výraznou orientací na svobodu a autonomii se kulturní kreativci neliší od řady jiných subkultur a postsubkultur (viz Muggleton 2000), ale v podstatě ani od mainstreamu. Co se týče environmentálních hodnot, kulturní kreativci nejsou v rozporu s většinovou společností, nebot' i u ní je zájem o životní prostředí vysoký (pro 94 \% Čechů je ochrana životního prostředí velmi či spíše důležitá; Krajhanzl - Chabada - Svobodová 2018: 23), ale kulturní kreativci se odlišují tím, že se snaží žít v souladu se svými hodnotami a reálně se angažují v oblasti udržitelnosti, a to často změnou 
svého jednání a životního stylu. Pro kulturní kreativce je často udržitelné praxi nadřazena změna vědomí, at' se přímo pojí s alternativní spiritualitou či ne (srv. Elgin 2010). Nesporné odlišnosti od amerických kulturních kreativců vidím ve vztahu k politice a politické angažovanosti, zdůrazňovaná apolitičnost je charakteristikou konkrétního vybraného média a nemusí platit pro celou subkulturu vzhledem $\mathrm{k}$ tomu, že některé kmeny či hnutí v rámci kulturních kreativců se angažují v protestu (kolem témat domácích porodů a neočkování).

Za kulturní kreativce můžeme označit segment společnosti, který sice v Česku netvoř́ čtvrtinu společnosti jako v USA a prozatím ho můžeme chápat jako alternativu, ale který se stále více rozšiřuje do společnosti a početně roste. Kulturní kreativci věří ve změnu skrze individuální jednání a chtějí jít ostatním příkladem. Proto se neuzavírají do exkluzivních skupin - jako to často dělají hudební subkultury mládeže -, ale snaží se pronikat do většinové společnosti, vytvářejí různé komunity, alternativní instituce a produkují řadu alternativních expertů, kteří nabízejí své zkušenosti formou vzdělávání, osobního rozvoje, poradenství či alternativního byznysu. Čeští kulturní kreativci se nevyvíjeli kumulací a konvergencí sociálních hnutí od 60. let, ale objevují se ve větší míře až v 21. století. Reagují už tak na jinou společnost, kde se individualismus stal normou, a proto vytváření kolektivní identity, i když třeba jen ve formě dočasných neotribálních setkání, má pro ně smysl. Odlišnosti od amerického pojetí jsou dané jednak lokálním vývojem hnutí a subkultur, ale také tím, že koncept Raye a Andersonové (2000) je už téměř 20 let starý a zejména po ekonomické krizi mohlo dojít k dalšímu vývoji této subkultury i ve Spojených státech.

Leden 2019

\section{Bibliografie}

Alan, Jan a kol. 2001. Alternationí kultura. Př́běh české společnosti 1945-1989. Praha: Lidové noviny.

Altheide, David. 1996. Qualitative Media Analysis. London: SAGE Publications. Bennett, Andy - Kahn-Harris, Keith. 2004. After Subculture. New York: Palgrave Macmillan.

Binka, Bohuslav. 2010. Zelený extremismus. Ideje a mentalita českých environmentalních hnutí. Brno: Masarykova univerzita.

Daniel, Ondřej a kol. 2016. Kultura svépomocí. Praha: Univerzita Karlova. Daniel, Ondřej. 2017. „Magické noci počal čas.“ New-age spiritualita a subkultury v čase změn. Studia Ethnologica Pragensia 1: 96-106. 
Duffková, Jana. 2006. Životní způsob/styl a jeho variantnost. In: Fazik, Alexander - Matějů, Martin (eds.): Aktuální problémy ziivotního stylu. Praha: Univerzita Karlova: 79-90.

Duffková, Jana - Urban, Lukáš - Dubský, Josef. 2008. Sociologie životního stylu. Plzeň: Aleš Čeněk.

Elgin, Duane. 2010. Voluntary Simplicity. New York: W. Morrow.

Fagan, Adam. 2004. Environment and Democracy in the Czech Republic. Cheltenham: Edward Elgar.

Florida, Richard. 2002. The Rise of the Creative Class. New York: Basic Books. Gordon, Milton M. 1997. The Concept of the Sub-culture and its Application. In: Gelder, Ken - Thornton, Sarah (eds.): The Subcultures Reader. London: Routledge: 40-54.

Haenfler, Ross - Johnson, Brett - Jones, Ellis. 2012. Lifestyle Movements: Exploring the Intersection of Lifestyle and Social Movements. Social Movement Studies 11: 1-20.

Hasmanová Marhánková, Jaroslava. 2014. Postoje rodičů odmítajících povinná očkování svých dětí. Sociologický časopis 50: 163-187.

Hrešanová, Ema. 2017. The Natural Childbirth in the Czech Republic. In: Fábián, Katalin - Korolczuk, Elzbieta (eds.): Rebellious Parents: Parental Movements in Central-Eastern Europe and Russia. Indianapolis: Indiana University Press: 277-307.

Heath, Joseph - Potter, Andrew. 2012. Kup si svou revoltu! Praha: Rybka Publishers.

Chaney, David. 2004. Fragmented Culture and Subcultures. In: Bennett, Andy - Kahn-Harris, Keith (eds.): After Subculture. New York: Palgrave Macmillan: 36-48.

Charvát, Jan - Kuř́́k Bob a kol. 2018. „Mikrofon je naše bomba." Politika a hudební subkultury mládeže v postsocialistickém Česku. Praha: Togga.

Irwin, John. 1997. Notes on the Status of the Concept Subculture. In: Gelder, Ken - Thornton, Sarah (eds.): The Subcultures Reader. London: Routledge: 66-70.

Kala, Lukáš - Galčanová, Lucie - Pelikán, Vojtěch. 2017. Narratives and Practices of Voluntary Simplicity in the Czech Post-Socialist Context. Czech Sociological Review 53: 833-856.

Kašparová, Irena. 2017. Domácí vzdělávání jako výraz kulturního kreativismu. Sociologický časopis 53: 79-100.

Kolářová, Marta (ed.). 2011. Revolta stylem. Hudební subkultury mládeže $v$ České republice. Praha: SLON.

Krajhanzl Jan - Chabada, Tomáš - Svobodová, Renata. 2018. Vztah české veřejnosti $k$ prírodě a životnímu prostředí. Brno: Muni press. 
Kramosilová, Jiřina. 2009. Zvonící cedry Ruska v kontextu spirituálních, environmentálních a utopických ideových konceptů. Diplomová práce. Brno: Masarykova univerzita.

Librová, Hana. 1994. Pestři a zelení. Kapitoly o dobrovolné skromnosti. Brno: Veronika.

Librová, Hana. 2003. Vlažní a váhaví. Kapitoly o ekologickém luxusu. Brno: Doplněk.

Librová, Hana - Pelikán, Vojtěch - Galčanová, Lucie - Kala, Lukáš. 2016. Vèrní a rozumní. Kapitoly o ekologické zpozdilosti. Brno: Masarykova univerzita.

Lužný, Dušan. 2004. Hledání ztracené jednoty. Prưniky nových náboženství a ekologie. Brno: Masarykova univerzita.

Maffesoli, Michel. 1996. The Time of the Tribes. London: Sage.

Matchar, Emily. 2013. Homeward Bound: Why Women Are Embracing the New Domesticity. New York: Simon \& Schuster.

Muggleton, David. 2000. Inside Subculture: the Postmodern Meaning of Style. Oxford: Berg.

Novák, Arnošt. 2017. Tmavozelený svět. Radikálně ekologické aktivity v ČR po roce 1989. Praha: SLON.

Nešpor, Zdeněk R. - Václavík, David a kol. 2008. Př́ručka sociologie náboženství. Praha: SLON.

Ondrašinová, Michaela. 2010. Jak uchopit „neuchopitelné“. Diskuse o detradicionalizované spiritualitě. In: Lužný, Dušan - Václavík, David a kol.: Individualizace náboženství a identita. Praha: Malvern: 118-144.

Ray, Paul H. - Anderson, Sherry Ruth. 2000. The Cultural Creatives: How 50 Million People are Changing the World. New York: Three Rivers Press. Roszak, Theodor. 2016. Zrod kontrakultury. Praha: Malvern.

Thornton, Sarah. 1997. General Introduction. In: Gelder, Ken - Thornton, Sarah (eds.): The Subcultures Reader. London: Routledge: 1-8.

Vojtíšek, Zdeněk. 2007. Nová náboženská hnutí a jak jim porozumět. Praha: Beta Books. 